\title{
Lipase Activity of Mycoplasma
}

\author{
By S. ROTTEM AND S. RAZIN \\ Department of Clinical Microbiology, Hebrew University-Hadassah Medical \\ School, Jerusalem, Israel
}

(Received 19 May 1964)

\begin{abstract}
SUMMARY
All of eight Mycoplasma strains tested were capable of hydrolysing tributyrin. The saprophytic Mycoplasma laidlawii strains showed the lowest lipolytic activity, and the parasitic Mycoplasma gallisepticum the highest. The properties of $\boldsymbol{M}$. gallisepticum lipase were studied in some detail. The lipolytic activity of this organism was highest at the logarithmic phase of growth and declined steeply afterwards. The enzyme was not bound to the cell membrane and appeared in the soluble fraction of disrupted cells. The cell extract hydrolysed tributyrin much faster than trilaurin or triolein. Methyl oleate and 'Tween 80 ' were only slowly hydrolysed. Cholesteryl acetate and stearate were not hydrolysed by cell extract or by intact $M$. gallisepticum. Partial purification of the lipase was accomplished by ammonium sulphate fractionation of cell-extract proteins, followed by anion-exchange chromatography. The partially purified enzyme did not require inorganic ions for activity and its optimal $\mathrm{pH}$ value varied between $7 \cdot 5$ and $8 \cdot 0$, depending on the substrate tested.
\end{abstract}

\section{INTRODUCTION}

In a study of the nutritional requirements of Mycoplasma for long-chain fatty acids, Mycoplasma laidlawii was found to utilize methyl oleate or 'Tween 80 ' as a source for oleic acid. There was evidence pointing to the enzymic hydrolysis of Tween 80 by this organism (Razin \& Rottem, 1963). The presence of lipases in Mycoplasma had long been suspected. During growth on horse-serum agar several Mycoplasma strains form a pearly film with little spots, found to consist of calcium and magnesium soaps; the film contained cholesterol and phospholipids (Edward, 1954). On media enriched with egg yolk, spots were formed by some additional strains which did not form them with horse serum. A clearing of egg-yolk medium by mycoplasmas was also noted. These observations prompted Edward (1954) to suggest that Mycoplasma strains contain lipases which break down phospholipids. These indications for an active lipid metabolism in Mycoplasma notwithstanding, very little was done to study the enzymes involved. Smith (1959) described cholesterol esterase activity in several Mycoplasma strains. One human strain was also found to contain a lipase which hydrolysed triglycerides. In view of the importance of lipids as essential nutrients and building blocks of the Mycoplasma cell membrane (Rodwell \& Abbott, 1961; Smith, 1963; Tourtellotte, Jensen, Gander \& Morowitz, 1963; Razin, Argaman \& Avigan, 1963) it seemed worthwhile to examine the lipid metabolism of these organisms. 


\section{METHODS}

Organisms. Mycoplasma laidlawii strain A (PG8), M. laidlawii strain B (PG9), $M$. mycoides var. mycoides ( $\mathrm{PG} 1$ ) and $M$. bovigenitalium ( $\mathrm{PG} 11$ ) were obtained from Dr D. G. ff. Edward (The Wellcome Research Laboratories, Beckenham, Kent, England). M. mycoides var. capri was provided by Dr E. Klieneberger-Nobel (The Lister Institute of Preventive Medicine, London). $M$. gallisepticum named (R) was obtained from Mrs Ruth Bernstein (Faculty of Agriculture, The Hebrew University, Rehovot, Israel). Strain s 6 of $M$. gallisepticum was provided by Dr H. E. Adler (School of Veterinary Medicine, University of California, Davis, U.S.A.). M. laidlawii (oral strain) was isolated in our laboratory from the human oral cavity. Most of the work to be described was done with $M$. gallisepticum (R).

Washed suspensions. The organisms were grown in 1 to 31 . volumes of a modified Edward medium (Razin, 1963) for 24-72 hr at $37^{\circ}$. The organisms were collected by centrifugation in a Sharples Supercentrifuge at $4^{\circ}$. The paste of organisms so obtained was resuspended in $0.25 \mathrm{M}-\mathrm{NaCl}$ solution and centrifuged at $16,000 \mathrm{~g}$ for $5 \mathrm{~min}$. at $4^{\circ}$. The sedimented organisms were then washed in cold $0.02 \mathrm{M}$-phosphate buffer ( $\mathrm{pH} 7 \cdot 5$ ) and resuspended in similar buffer. The amount of organisms in suspension was expressed as mg. cell protein $/ \mathrm{ml}$. suspension. In suspensions of the main test organism, $M$. gallisepticum $(\mathbf{R})$, cellular protein was determined by comparing the extinction at $500 \mathrm{~m} \mu$ to a previously prepared standard curve, which related extinction and cellular protein. Protein was determined by the method of Lowry, Rosebrough, Farr \& Randall (1951).

Cell-free extracts. Mycoplasma gallisepticum organisms were disrupted in an M.S.E. ultrasonic disintegrator $(60 \mathrm{~W}$.). Seven ml. of a heavy suspension of the washed organisms in $0.02 \mathrm{M}$-phosphate buffer $(\mathrm{pH} \mathrm{7.5)}$ were treated at $1.5 \mathrm{amp}$. for $2.5 \mathrm{~min}$. Cell debris was removed by centrifugation at $34,000 \mathrm{~g}$ for $30 \mathrm{~min}$. and the supernatant fluid separated and kept at $-20^{\circ}$ until used.

Chemicals. Tri- $n$-butyrin, di- $n$-butyrin, 1-monobutyrin and mono-olein were obtained from Eastman Organic Chemicals (Rochester 3, New York, U.S.A.). Triolein and trilaurin were the products of Mann Research Laboratories (New York 6, N.Y., U.S.A.). Methyl oleate, cholesteryl acetate and cholesteryl stearate were obtained from Nutritional Biochemicals Corporation (Cleveland, Ohio, U.S.A.). Aqueous emulsions of lipids were prepared by ultrasonic treatment. The lipid (about $200 \mu$ moles) was dissolved in diethyl ether (1-2 ml.) and the solution injected with a syringe into $15 \mathrm{ml}$. of $0.02 \mathrm{M}$-phosphate buffer containing 0.02 M-2-hydroxymethylpropane-1:3-diol (tris) buffer ( $\mathrm{pH} 7 \cdot 7$; subsequently this will be referred to as phosphate tris buffer). The buffer solution contained in addition $200 \mu$ mole sodium taurocholate. The suspension was immediately treated in an M.S.E. ultrasonic disintegrator at $1.5 \mathrm{amp}$. for $4 \mathrm{~min}$. without cooling. During this treatment the temperature of the emulsion reached $40^{\circ}$, causing the ether to evaporate. These emulsions obtained remained stable for at least several days.

\section{Determination of lipolytic activity}

Qualitative assays. Edward medium plates containing $0.4 \%(\mathrm{w} / \mathrm{v})$ tributyrin were prepared. Tributyrin dissolved in a small volume of acetone was added to basal 
Edward medium containing Bacto-heart infusion broth, Bacto-peptone, $\mathrm{NaCl}$ and Bacto-agar (Razin \& Oliver, 1961; Razin, 1963). The medium was autoclaved at $121^{\circ}$ for $20 \mathrm{~min}$., cooled to $50^{\circ}$ and all the other ingredients (Razin, 1963) added. The medium, still liquid, was transferred to a sterile $50 \mathrm{ml}$. beaker and treated in the ultrasonic disintegrator at $1.5 \mathrm{amp}$. for $3 \mathrm{~min}$. Twelve ml. volumes of this medium were then poured into sterile Petri dishes and allowed to solidify. In some experiments the tributyrin plates were covered with a thin film of polyvinyl formal ('Formvar', Shawinigan Ltd., London, E.C. 3). A solution of $0.5 \%$ (w/v) Formvar in chloroform was quickly poured on the surface of the agar, and allowed to drain off by inclining the plates. After evaporation of the chloroform a fine film of Formvar was produced on the agar surface. This film was freely permeable to medium nutrients, but prevented direct contact of Mycoplasma organisms placed on top of it, with the medium underneath. The organisms to be tested were grown in $5 \mathrm{ml}$. volumes of liquid Edward medium for 24-48 hr and washed as described above. The washed organisms obtained from a $5 \mathrm{ml}$. culture were suspended in $0 \cdot 3 \mathrm{ml}$. of $0.02 \mathrm{M}$ phosphate buffer ( $\mathrm{pH} \mathrm{7.5)}$ ) and $0.02 \mathrm{ml}$. drops of these suspensions were placed on the tributyrin plates. The plates were incubated at $37^{\circ}$ for $24 \mathrm{hr}$; clear zones which appeared in and around the drop areas indicated lipolytic activity.

A simple semi-quantitative method for estimating lipase activity in chromatographic fractions of Mycoplasma proteins was devised. Tributyrin, dissolved in a small volume of acetone, was added in a final concentration of $0.4 \%(w / v)$ to $0.02 \mathrm{M}$ phosphate buffer ( $\mathrm{pH} \mathrm{7.5)} \mathrm{containing} \mathrm{0.9 \%} \mathrm{(w/v)} \mathrm{Bacto-agar.} \mathrm{The} \mathrm{medium} \mathrm{was}$ autoclaved at $121^{\circ}$ for 20 min., cooled to $50^{\circ}$ and treated in the ultrasonic disintegrator at $1.5 \mathrm{amp}$. for $3 \mathrm{~min}$. Twelve $\mathrm{ml}$. volumes of the resulting suspensions were poured into sterile Petri dishes and allowed to solidify. Drops $(0.02 \mathrm{ml}$.) of each of the chromatographic fractions were placed on the plates, which were then incubated at $37^{\circ}$ for $\mathbf{2 4} \mathrm{hr}$. The presence and degree of lipolytic activity in these fractions could be then estimated by the size of the clear zones which appeared in the drop areas (Pl. 1, fig. 1).

Quantitative assays. The reaction mixtures were usually composed of washed organisms, cell extracts or chromatographic fractions in $0.02 \mathrm{M}$-phosphate buffer (pH 7.5). The lipid was added to the reaction mixture as a finely dispersed suspension prepared by ultrasonic treatment as described above. Thallium acetate, which did not affect lipolytic activity, was added to a final concentration of $0.04 \%(\mathrm{w} / \mathrm{v})$ to prevent growth of contaminating organisms during long incubation periods. The total volume of the reaction mixture was 5-10 ml. Experiments with washed organisms or cell-free extracts were done in $100 \mathrm{ml}$. Erlenmeyer flasks shaken in a $37^{\circ}$ water bath. Lipase activity in chromatographic fractions was assayed in test tubes incubated statically at $37^{\circ}$. Hydrolysis of tri-, di- and monobutyrin was determined by titration of freed butyric acid with $0.01 \mathrm{~N}-\mathrm{NaOH}$, measured by a glass electrode. Hydrolysis of triglycerides and other esters of long-chain fatty acids was determined according to Dole (1956). The liberated long-chain fatty acids were eluted from the reaction mixture with heptane + water + isopropanol $(\mathbf{3 6}+\mathbf{2 8}+\mathbf{3 6}$, by vol.) and titrated with $0.02 \mathrm{~N}-\mathrm{NaOH}$, with Nile blue as indicator. Corrections were always made for titritable acidity of reaction mixtures containing boiled organisms, cell extracts or chromatographic fractions. One enzyme unit was defined as that amount which under the conditions of the test liberated $1 \mu$ equiv. 
of acid $/ 6 \mathrm{hr}$. Specific activity of the lipase was defined as the number of enzyme units/mg. protein in the volume of reaction mixture titrated.

For measurement of tributyrin hydrolysis by cell extracts or chromatographic fractions, a rapid turbidimetric method was devised. A suspension containing $32 \mu$ moles tributyrin/ml. in 0.02 M-phosphate buffer ( $\mathrm{pH} \mathrm{7.5)}$ was prepared by ultrasonic treatment at $1.5 \mathrm{amp}$. for $3 \mathrm{~min}$. Three ml. samples of cell extracts or chromatographic fractions in $0.02 \mathrm{M}$-phosphate buffer $\left(\mathrm{pH} \mathrm{7.5)}\right.$ were incubated in a $37^{\circ}$ water bath. Each sample received $0.2 \mathrm{ml}$. tributyrin suspension and the extinction was measured immediately in a 'Unicam SP 500' spectrophotometer at $625 \mathrm{~m} \mu$ : Decrease in extinction of suspensions was determined after 10 and $20 \mathrm{~min}$. of incubation at $37^{\circ}$. Corrections were made for the decrease of extinction in a control tube containing tributyrin suspended in 0.02 M-phosphate buffer ( $\mathrm{pH} \mathrm{7.5)}$. The extinction in the control tube during the incubation period decreased only (slightly by not more than 0.03 unit scale reading at $625 \mathrm{~m} \mu$ ). One enzyme unit, according to the turbidimetric method, was defined as that amount which under the conditions of the test caused a decrease of 0.01 unit scale reading at $625 \mathrm{~m} \mu$ after $20 \mathrm{~min}$. incubation. Specific activity of the lipase was defined as the number of enzyme units/mg. protein in $1 \mathrm{ml}$. of reaction mixture.

Hydrolysis of cholesteryl esters was measured by titration of the free acid liberated according to Dole (1956) and by colorimetric determination of the free cholesterol formed. Free cholesterol was separated from its esters by thin-layer chromatography (Razin et al. 1963; Argaman \& Razin, to be published) and estimated by the $\mathrm{FeCl}_{3}$ reaction (Wycoff \& Parsons, 1957).

Partial purification of lipase. Ammonium sulphate was added to cell extract of Mycoplasma gallisepticum (R) to $50 \%$ saturation $(31 \cdot 3 \mathrm{~g} . / 100 \mathrm{ml}$.). The solution was left overnight at $4^{\circ}$; the resulting precipitate was centrifuged down at $25,000 \mathrm{~g}$ for $\mathrm{l} \mathrm{hr}$ in the cold, and discarded. More ammonium sulphate was then added to the supernatant fluid to $80 \%$ saturation $(24.8 \mathrm{~g} . / 100 \mathrm{ml}$.) and the solution kept overnight at $4^{\circ}$. This second precipitate was collected by centrifugation at $25,000 \mathrm{~g}$ for $1 \mathrm{hr}$ at $4^{\circ}$ and dissolved in $0.02 \mathrm{M}$-phosphate buffer $(\mathrm{pH} \mathrm{7.5)}$. The solution was then dialysed at $4^{\circ}$ for $15 \mathrm{hr}$ against the same buffer with constant stirring. The buffer was changed several times during this dialysis. A granular precipitate which appeared in the dialysis bag was separated by centrifugation and discarded. The clear protein solution was then chromatographed on a DEAE-Sephadex A-50 (medium) column. Fractions were collected by a fraction collector and tested for lipase activity. The fractions containing lipase activity were combined, dialysed against de-ionized water overnight at $4^{\circ}$ and freeze-dried.

Analytical methods. Butyric acid liberated during hydrolysis of tributyrin was identified by paper chromatography (Block, Durrum \& Zweig, 1958). The developing solvent was $n$-propanol + concentrated ammonia, sp.gr. $0 \cdot 880(70+30$, by vol. $)$. The paper was sprayed with an aqueous solution of bromophenol blue $(0.05 \%, \mathrm{w} / \mathrm{v})$ acidified with citric acid $(0 \cdot 2 \%, w / v)$. The ammonium salt of butyric acid appeared on the paper as a blue spot on a yellow background.

Degradation products of triglycerides containing long-chain fatty acids were identified by thin-layer chromatography. The chromatoplates were covered with silica gel G containing Rhodamine (Razin et al. 1963). The lipid to be chromatographed was dissolved in a small volume of benzene and applied to the plates as a 
short band. The developing solvent was light petroleum (B.P. $40-60^{\circ}$ ) + diethyl ether $(50+50$, by vol.) and the running time was about $1 \mathrm{hr}$. After chromatography, the tri-, di- and monoglycerides were visible under ultraviolet radiation as pink-yellow fluorescent areas on a pale-green background.

\section{RESULTS}

Occurrence of lipolytic activity in various Mycoplasma strains

All the Mycoplasma strains tested were found to hydrolyse tributyrin when grown on Edward medium plates containing this substrate (Pl. 1, fig. 2). The saprophytic Mycoplasma laidlawii strains showed the lowest lipolytic activity and the parasitic $M$. gallisepticum strains the highest (Table 1). Most of the work was therefore carried out with $M$. gallisepticum strains.

\section{Table 1. Hydrolysis of tributyrin by various Mycoplasma strains}

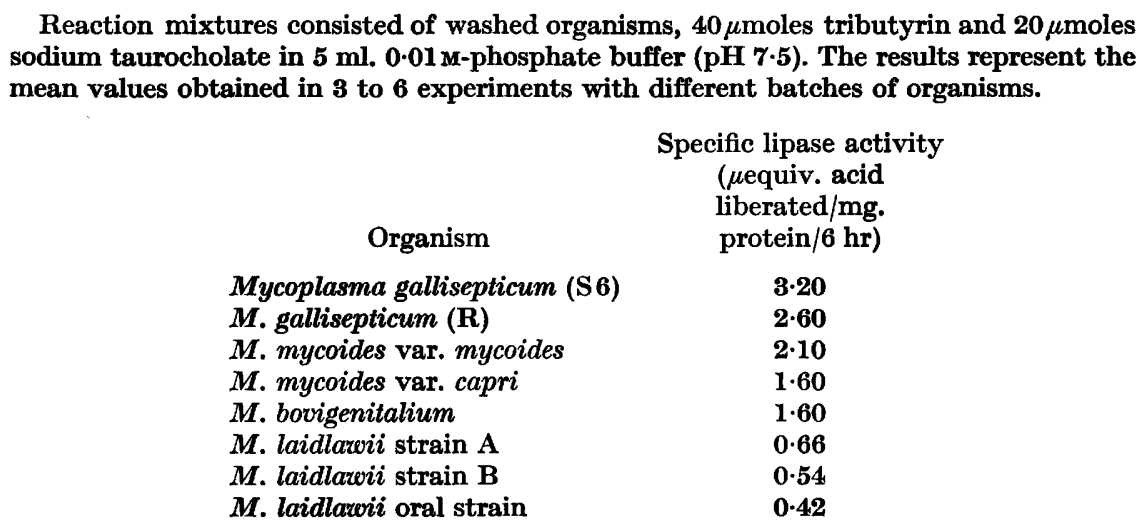

\section{Localization of lipase activity in the Mycoplasma organism}

The hydrolysis of tributyrin in and around the growth areas on tributyrin plates (Pl. 1, fig. 2) suggested that lipases of Mycoplasma are soluble and not cell-bound. Tributyrin was also hydrolysed by organisms grown on a Formvar film which prevented direct contact between the organisms and the substrate in the growth medium. When Mycoplasma gallisepticum organisms were disrupted by ultrasonic treatment, the lipase activity was found in the fraction not sedimented by centrifugation at 34,000 $\mathrm{g}$ for $30 \mathrm{~min}$. (Fig. 1). Lipolytic activity in this 'soluble' fraction was maximal after ultrasonic treatment for 1.5-2.5 min. Further treatment diminished enzymic activity, probably because of denaturation of proteins by the ultrasonic treatment (Hughes, 1961). Lipase activity in the cell-debris fraction was much lower than in the 'soluble' fraction. On centrifugation of the 'soluble' fraction at $100,000 \mathrm{~g}$ for $30 \mathrm{~min}$. the lipolytic activity remained in the supernatant fluid; the sediment was practically lipase-free. Lipase activity of cell-free extracts of $M$. gallisepticum did not significantly decrease during 6 months storage at $4^{\circ}$. 


\section{Relation of lipase activity to age of culture}

The lipolytic activity of Mycoplasma gallisepticum whole organisms and cel extracts was highest at the logarithmic phase of growth, declining steeply after. wards. This decline paralleled the rapid death of $M$. gallisepticum in the glucose containing Edward medium (Fig. 2).

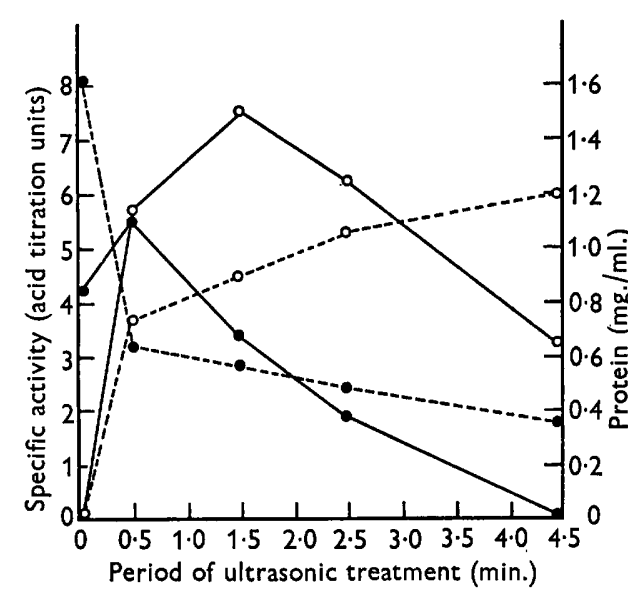

Fig. 1

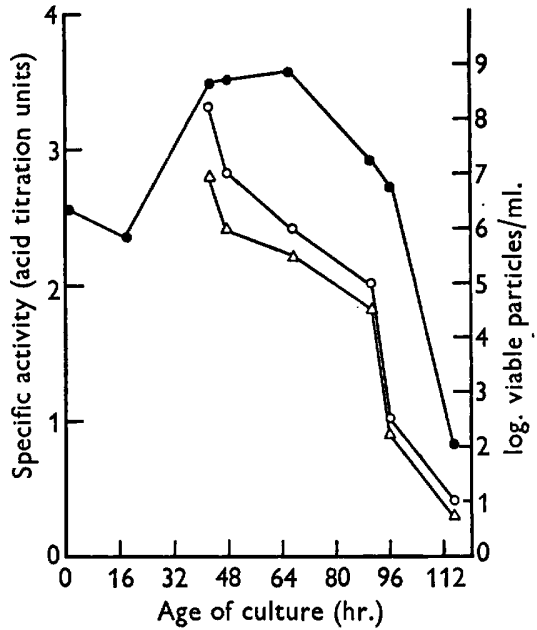

Fig. 2

Fig. 1. Lipase activity of extract and debris of Mycoplasma gallisepticum (R) organisms treated ultrasonically for various periods of time. Cell debris was separated from cell extract by centrifugation at $34,000 \mathrm{~g}$ for $30 \mathrm{~min}$. Lipase activity was determined in the fractions obtained, with tributyrin as substrate. Cell extract $(O)$; cell debris (O). $\longrightarrow$, lipase activity; - - -, protein content of cell fraction.

Fig. 2. Lipase activity of Mycoplasma gallisepticum (R) harvested at different phases of growth. Lipase activity was determined as described in Table 1 , with tributyrin as substrate. Lipase activity of washed organisms $(\triangle)$ and of cell-extracts $(O)$. Number of viable particles (O) determined according to Butler \& Knight (1960).

\section{Specificity of Mycoplasma gallisepticum lipase towards various substrates}

The cell extract of Mycoplasma gallisepticum hydrolysed glycerides of short- and long-chain fatty acids. Tributyrin was hydrolysed at a much higher rate than was trilaurin or triolein. The oleic acid esters, methyl oleate and 'Tween 80', were also hydrolysed, but only slowly (Table 2). The optimal $\mathrm{pH}$ value for hydrolysis varied with the nature of the substrate; thus mono-, di- and tributyrin were best hydro-

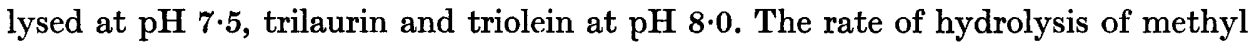
oleate and ' $T w e e n ~ 80$ ' was about the same at $\mathrm{pH} \mathrm{7.5}$ and 8.0 (Table 2). During the hydrolysis of triolein and trilaurin the corresponding di- and monoglycerides appeared in the reaction mixture, as shown by thin-layer chromatography. Cholesteryl acetate and stearate were not hydrolysed by washed organisms or extracts of M. gallisepticum (R) or by washed organisms of $M$. gallisepticum (S6). During the incubation no free fatty acids were liberated from the cholesteryl esters (Table 2), and the amount of free cholesterol did not increase, as shown by thin-layer chromatography. Hydrolysis of cholesteryl esters was tested at various $\mathrm{pH}$ values ranging from $6 \cdot 5$ to $9 \cdot 0$. 


\section{Partial purification of Mycoplasma gallisepticum lipase}

The lipase of Mycoplasma gallisepticum was precipitated between 50 and $80 \%$ saturation with ammonium sulphate. The precipitated proteins were chromatographed on a DEAE-Sephadex A-50 column. Fractions 6 to 10 eluted from the column showed lipase activity, rising to a sharp peak in fractions 7 and 8 (Fig. 3 ). Table 3 summarizes the steps involved in the purification of the lipase, the degree of purification and the yield of enzyme.

\section{Table 2. Substrate specificity of Mycoplasma gallisepticum lipase}

The reaction mixture consisted of $5 \mathrm{ml}$. M. gallisepticum cell extract in $0.02 \mathrm{M}$-phosphate tris buffer, containing $20 \mu$ moles sodium taurocholate and substrate in the amounts indicated in the table.

\begin{tabular}{|c|c|}
\hline Substrate & mixture \\
\hline Tributyrin (20 $\mu$ moles) & $\begin{array}{l}7 \cdot 5 \\
8 \cdot 0\end{array}$ \\
\hline Dibutyrin (30 $\mu$ moles) & $\begin{array}{l}7 \cdot 5 \\
8 \cdot 0\end{array}$ \\
\hline 1-Monobutyrin (60 $\mu$ moles) & $\begin{array}{l}7 \cdot 5 \\
8 \cdot 0\end{array}$ \\
\hline Trilaurin (20 $\mu$ moles) & $\begin{array}{l}7 \cdot 5 \\
8 \cdot 0\end{array}$ \\
\hline Triolein (20 $\mu$ moles) & $\begin{array}{l}7 \cdot 5 \\
8 \cdot 0\end{array}$ \\
\hline Methyl oleate (60 $\mu$ moles) & $\begin{array}{l}7 \cdot 5 \\
8 \cdot 0\end{array}$ \\
\hline Tween $80(1 \%, w / v)$ & $\begin{array}{l}7 \cdot 5 \\
8 \cdot 0\end{array}$ \\
\hline Cholesteryl stearate ( $20 \mu$ moles) & $\begin{array}{l}7 \cdot 5 \\
8 \cdot 0\end{array}$ \\
\hline
\end{tabular}

\begin{tabular}{|c|c|c|}
\hline \multirow{2}{*}{$\begin{array}{l}\text { pH value of } \\
\text { reaction } \\
\text { mixture }\end{array}$} & \multicolumn{2}{|c|}{$\mu$ equiv. acid liberated/mg. protein in } \\
\hline & $6 \mathrm{hr}$ & $24 \mathrm{hr}$ \\
\hline $7 \cdot 5$ & $6 \cdot 52$ & $\mathbf{9 \cdot 2 0}$ \\
\hline $8 \cdot 0$ & 4.54 & 6.90 \\
\hline $7 \cdot 5$ & $4 \cdot 23$ & 一 \\
\hline $8 \cdot 0$ & $\mathbf{2} \cdot \mathbf{8 2}$ & 一 \\
\hline $7 \cdot 5$ & 3.04 & - \\
\hline $8 \cdot 0$ & $\mathbf{2} \cdot 39$ & - \\
\hline $7 \cdot 5$ & 0.07 & $0 \cdot 21$ \\
\hline $8 \cdot 0$ & $0 \cdot 42$ & $0 \cdot 96$ \\
\hline $7 \cdot 5$ & 0.06 & $0 \cdot 16$ \\
\hline $8 \cdot 0$ & $0 \cdot 32$ & 0.62 \\
\hline $7 \cdot 5$ & $0 \cdot 10$ & $\mathbf{0 \cdot 2 3}$ \\
\hline $8 \cdot 0$ & $0 \cdot 12$ & $\mathbf{0 . 2 4}$ \\
\hline $7 \cdot 5$ & $\mathbf{0} \cdot \mathbf{2 2}$ & 0.52 \\
\hline $8 \cdot 0$ & $0 \cdot 26$ & $\mathbf{0 . 5 2}$ \\
\hline $7 \cdot 5$ & $\mathbf{0}$ & $\mathbf{0}$ \\
\hline 8.0 & 0 & 0 \\
\hline
\end{tabular}

Table 3. Partial purification of Mycoplasma gallisepticum lipase

\begin{tabular}{|c|c|c|c|c|c|c|}
\hline Step & Preparation & $\begin{array}{c}\text { Volume } \\
\text { (ml.) }\end{array}$ & $\begin{array}{c}\text { Protein } \\
(\mathrm{mg} . / \mathrm{ml} .)\end{array}$ & $\begin{array}{c}\text { Specific } \\
\text { activity* }\end{array}$ & $\begin{array}{c}\text { Degree of } \\
\text { purification }\end{array}$ & $\begin{array}{l}\text { Yield } \\
(\%)\end{array}$ \\
\hline 1 & Crude cell extract & $20 \cdot 0$ & $\mathbf{3} \cdot 45$ & $20 \cdot 4$ & $1 \cdot 0$ & $100 \cdot 0$ \\
\hline $\mathbf{2}$ & $\begin{array}{l}\text { Supernatant fluid obtained } \\
\text { after } 50 \% \text { saturation with } \\
\left(\mathrm{NH}_{4}\right)_{2} \mathrm{SO}_{4}\end{array}$ & $29 \cdot 0$ & $1 \cdot 04$ & $33 \cdot 0$ & $1 \cdot 6$ & $69 \cdot 4$ \\
\hline $\mathbf{3}$ & $\begin{array}{c}\text { Precipitate formed at } 80 \% \\
\text { saturation with }\left(\mathrm{NH}_{4}\right)_{2} \mathrm{SO}_{4}\end{array}$ & $\mathbf{2 \cdot 2}$ & $8 \cdot 70$ & $\mathbf{4 5 \cdot 0}$ & $\mathbf{2 \cdot 2}$ & $61 \cdot 8$ \\
\hline 4 & $\begin{array}{l}\text { Chromatography on DEAE- } \\
\text { Sephadex A-50 }\end{array}$ & & & & & \\
\hline & Fraction 7 & $4 \cdot 0$ & 0.052 & $594 \cdot 0$ & $27 \cdot 6)$ & \\
\hline & Fraction 8 & $4 \cdot 0$ & $0 \cdot 050$ & $495 \cdot 0$ & $24 \cdot 1\}$ & $25 \cdot 6$ \\
\hline & Fraction 9 & $4 \cdot 0$ & 0.036 & $450 \cdot 0$ & $22 \cdot 0$ & \\
\hline
\end{tabular}




\section{Properties of the partially purified lipase}

The hydrolysis of the various triglycerides increased at about the same rate during the purification procedure (Table 4). Tributyrin was used as substrate in testing the properties of the partially purified lipase. Optimal temperature for activity was $37^{\circ}$ and pH 7.5 was optimal (Fig. 4). The partially purified lipase was completely inactivated by heating at $65^{\circ}$ for $10 \mathrm{~min}$. (Fig. 5), and was rapidly inactivated when

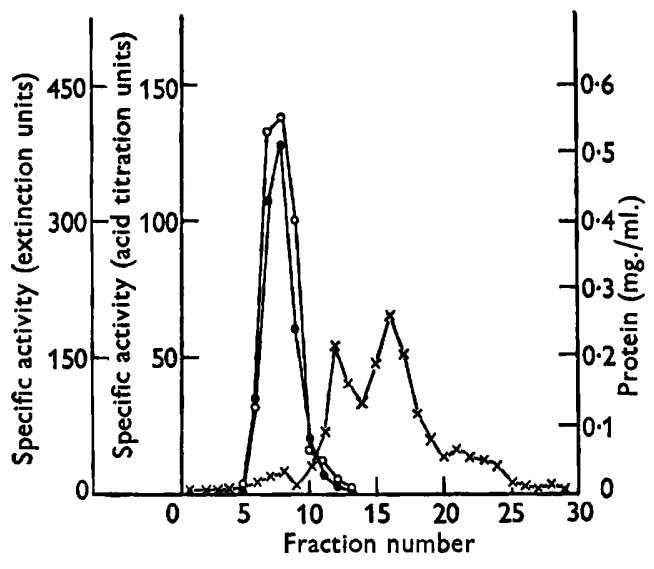

Fig. 3

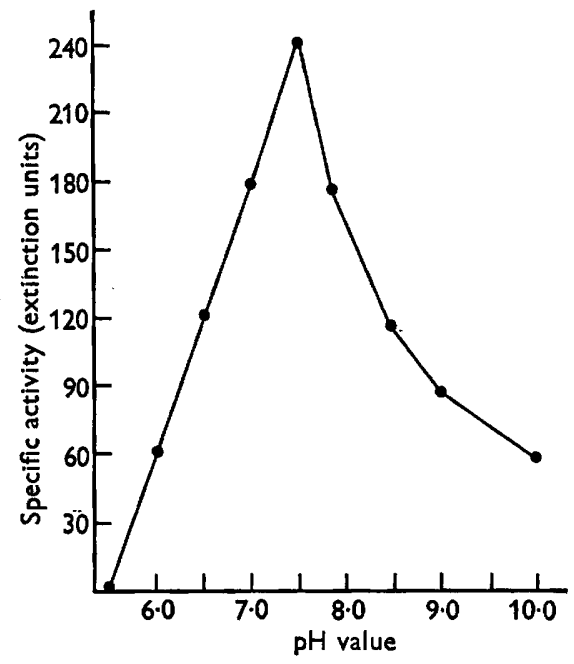

Fig. 4

Fig. 3. Partial purification of Mycoplasma gallisepticum lipase by anion-exchange chromatography of cell-extract proteins. Two ml., containing $12 \mathrm{mg}$. protein obtained by ammonium sulphate precipitation, were placed on a DEAE-Sephadex A-50 (medium) column $(1.4 \times 14 \mathrm{~cm}$.) equilibrated with $0.02 \mathrm{M}$-phosphate buffer (pH 7.5). Elution was performed by successive addition of $29 \mathrm{ml}$. volumes of $\mathrm{NaCl}$ solution of increasing molarity $(0.1,0.2,0.3,0.4,0.5$ and $0.6 \mathrm{M}-\mathrm{NaCl}$ in $0.02 \mathrm{M}$-phosphate buffer, $\mathrm{pH} \mathrm{7.5})$. Flow rate was about $20 \mathrm{ml}$. $/ \mathrm{hr}$ and fraction volume $4 \mathrm{ml}$. Hydrolysis of tributyrin by all fractions was tested by the acid titration (O) or by the turbidimetric ( $O$ ) method. Protein concentration in fractions $(x)$.

Fig. 4. Effect of $\mathrm{pH}$ value on the hydrolysis of tributyrin by the partially purified lipase of Mycoplasma gallisepticum. Lipase activity was determined by the turbidimetric method. The reaction mixtures contained 0.02M-phosphate tris buffer.

Table 4. Comparison of the hydrolysis rate of various triglycerides by the partially purified lipase and cell extract of Mycoplasma gallisepticum $(\boldsymbol{R})$

Reaction mixtures as in Table 2. Hydrolysis of tributyrin was tested at $\mathrm{pH} 7.5$ and that of trilaurin and triolein at $\mathbf{p H} 8 \cdot 0$.

\begin{tabular}{|c|c|c|}
\hline \multirow[t]{2}{*}{ 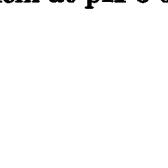 } & \multicolumn{2}{|c|}{$\begin{array}{l}\text { Specific lipase activity } \\
\text { (acid titration units) }\end{array}$} \\
\hline & $\begin{array}{c}\text { Partially } \\
\text { purified } \\
\text { lipase }\end{array}$ & Cell extract \\
\hline Tributyrin & $55 \cdot 20$ & $\mathbf{2 \cdot 8 0}$ \\
\hline Trilaurin & $4 \cdot 21$ & 0.24 \\
\hline Triolein & $\mathbf{8 . 8 0}$ & 0.15 \\
\hline
\end{tabular}


incubated in highly acid or alkaline solutions (Fig. 6). The divalent cations magnesium, calcium and manganese did not stimulate lipase activity. Prolonged dialysis of the enzyme solution, or addition of ethylenediaminetetra-acetic acid (EDTA) in a final concentration of $0.025 \mathrm{~m}$ did not affect enzymic activity.

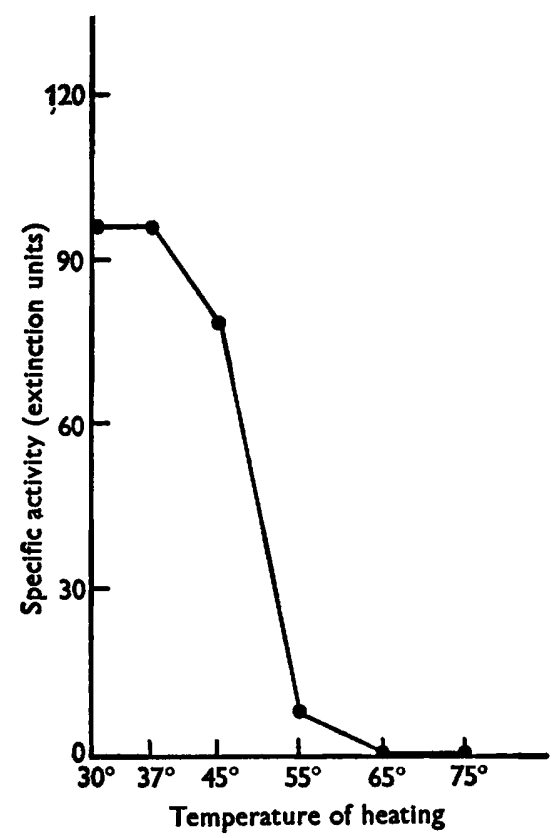

Fig. 5

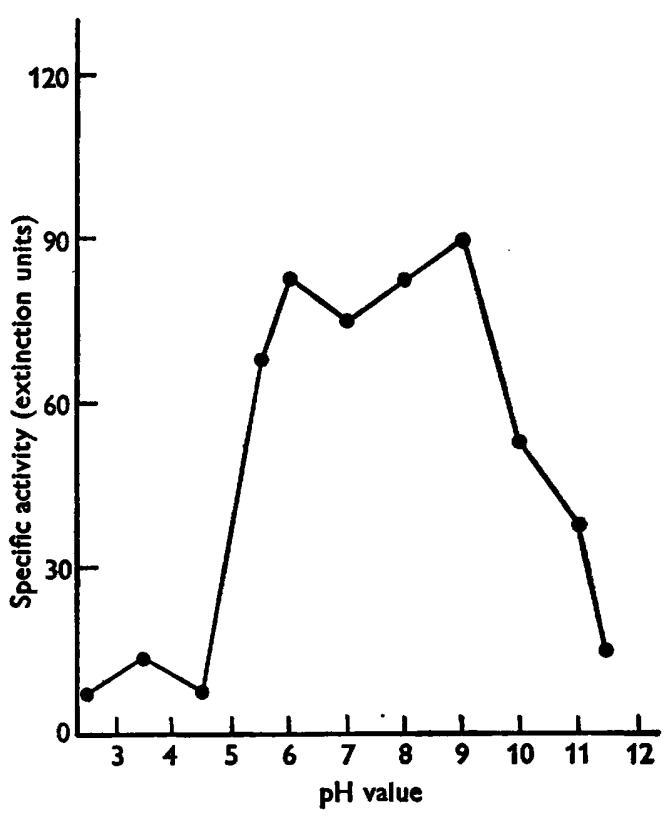

Fig. 6

Fig. 5. Heat inactivation of Mycoplasma gallisepticum lipase. The partially purified enzyme solution was heated for $10 \mathrm{~min}$. at the temperatures indicated in the figure. Hydrolysis of tributyrin by the heated solutions was tested turbidimetrically.

Fig. 6. Inactivation of Mycoplasma gallisepticum lipase in acid or alkaline solutions. The $\mathrm{pH}$ value of the partially purified enzyme solution in $0.02 \mathrm{M}$-phosphate buffer was adjusted with $0.1 \mathrm{~N}-\mathrm{HCl}$ or $0.1 \mathrm{~N}-\mathrm{NaOH}$ to the values indicated in the figure. The enzyme solutions were incubated at $37^{\circ}$ for $30 \mathrm{~min}$. The ability of these solutions to hydrolyse tributyrin was tested after re-adjustment to $\mathrm{pH} \mathbf{7 \cdot 5}$.

\section{DISCUSSION}

The hydrolysis of tributyrin by all eight of the Mycoplasma strains tested indicated the widespread occurrence of lipolytic activity in this group of organisms. The saprophytic Mycoplasma laidlawii strains showed a much lower lipolytic activity than the parasitic strains. The saprophytic strains have already been found to differ from the parasitic strains in their nutritional requirements (Razin, 1962), lipid composition (Rothblat \& Smith, 1961; Razin, Argaman \& Avigan, 1963) and osmotic fragility (Razin, 1963). The lipases of mycoplasmas seem to resemble lipases of other micro-organisms in being soluble and not cell-bound (Davies, 1954). This was clearly shown for the lipase of $\boldsymbol{M}$. gallisepticum. However, lipase activity of a human Mycoplasma strain was found to be associated with the cell membrane by Smith (1959).

The steep decline in the lipolytic activity of Mycoplasma gallisepticum at the end 
of the logarithmic phase of growth may be explained in several ways. Activity may decline owing to oxidation or digestion of the lipase by autolytic enzymes (Sierra, 1957). The enzyme may be denatured by the high acidity developed in the growth medium; the $\mathrm{pH}$ value of Edward medium containing glucose $(0.5 \%, \mathrm{w} / \mathrm{v})$ decreases to $\mathrm{pH} 5 \cdot 2-5 \cdot 4$ during the decline phase of growth. At this low $\mathrm{pH}$ value the partially purified lipase of $M$. gallisepticum lost most of its activity (Fig. 6). The soluble lipase might also diffuse out of dying organisms. We detected no lipase activity in the growth medium after removal of the organisms. This may, however, be due to the relatively low activity of the lipase and its dilution in the growth medium.

The cell extract and the partially purified lipase of Mycoplasma gallisepticum hydrolysed triglycerides of short- and long-chain fatty acids, as well as methyl oleate and Tween 80 . The rate of hydrolysis of trilaurin or triolein was only 1-10\% of that of tributyrin. The optimal $\mathrm{pH}$ value for hydrolysis also varied with the nature of the substrate. Dependence of the rate of hydrolysis and the optimal $\mathrm{pH}$ value on the nature of the substrate is a well-known characteristic of many lipases (Goldman \& Rayman, 1952; Nashif \& Nelson, 1953; Bier, 1955). Hence one enzyme only may be responsible for the hydrolysis of the various substrates by $M$. gallisepticum. The unchanged substrate specificity following purification of the lipase supports this assumption. The inability of $\boldsymbol{M}$. gallisepticum organisms and cell extracts to hydrolyse cholesteryl esters has also been observed when radioactive cholesteryl oleate was used. M. gallisepticum incorporated this ester from the growth medium, but did not hydrolyse it (Argaman \& Razin, to be published).

Formation of a film and spots in the growth medium due to degradation of lipids serves as a criterion for the classification of Mycoplasma (Edward, 1954; Freundt, 1958). In view of our results strictly defined conditions should be prescribed for this test. Mycoplasma laidlawii, for example, which is classified as a 'non-film and spots' producer (Freundt, 1958), will form a film and spots when Tween 80 and $\mathrm{CaCl}_{2}$ supplement the Edward medium (Razin \& Rottem, 1963).

The role of lipases in the physiology of Mycoplasma is yet to be elucidated. The lipases may hydrolyse lipids in the growth medium and liberate long-chain fatty acids required for growth of Mycoplasma (Rodwell \& Abbott, 1961; Tourtellotte et al. 1963; Razin \& Rottem, 1963). On the other hand, the liberated long-chain fatty acids may have a deleterious effect on the organisms when they accumulate above a certain concentration in the growth medium. The mycoplasmas, having only a thin lipoprotein membrane, are very susceptible to lysis by surface-active substances, including long-chain fatty acids (Edward \& Fitzgerald, 1951; Rodwell, 1956; Smith \& Boughton, 1960; Razin \& Rottem, 1963).

This work forms part of an investigation made by S. Rottem in partial fulfilment of the requirements for the Ph.D. degree at the Hebrew University, Jerusalem. The study was supported in part by a grant from the Joint Research Fund of the Hebrew University-Hadassah Medical School.

\section{REFERENCES}

Bier, M. (1955). Lipases. Methods in Enzymology, 1, 627. Ed. S. P. Colowick \& N. O. Kaplan. New York: Academic Press Inc.

Block, R. J., Durrum, E. L. \& Zweig, G. (1958). A Manual of Paper Chromatography and Paper Electrophoresis. 2nd ed. New York: Academic Press Inc. 
Butler, M. \& Knight, B. C. J. G. (1960). The survival of washed suspensions of Mycoplasma. J. gen. Microbiol. 22, 470.

Davies, M. E. (1954). A study of the diffusible lipase produced by staphylococci and its immunological activity. J. gen. Microbiol. 11, 37.

Dole, V.P. (1956). A relation between non-esterified fatty acids in plasma and the metabolism of glucose. J. clin. Invest. 35, 150.

EDwARD, D. G. FF.(1954). The pleuropneumonia group of organisms : a review together with some new observations. J. gen. Microbiol. 10, 27.

EDward, D. G. FF. \& Fitzgeraid, W. A. (1951). Cholesterol in the growth of the pleuropneumonia group. J. gen. Microbiol. 5, 576.

Freundt, E. A. (1958). The Mycoplasmataceae (The pleuropneumonia group of organisms). Morphology, Biology and Taxonomy. Copenhagen: Munksgaard.

Goldman, M. L. \& RaYman, M. M. (1952). Hydrolysis of fats by bacteria of the Pseudomonas genus. Food Res. 17, 326.

Hughes, D. E. (1961). The disintegration of bacteria and other microorganisms by the M.S.E.-Mullard ultrasonic disintegrator. J. biochem. microbiol. Technology \& Engineering, 3,405 .

Lowry, O. H., Rosebrough, N. J., Farr, A. L. \& Randall, R. J. (1951). Protein measurement with the folin phenol reagent. J. biol. Chem. 193, 265.

NASHIF, S. A. \& Nelson, F. E. (1953). The lipase of Pseudomonas fragi. I. Characterization of the enzyme. J. Dairy Sci. 36, 459.

RAZIN, S. (1962). Nutrition and metabolism of pleuropneumonia-like organisms. In Pleuropneumonia-like Organisms (PPLO) Mycoplasmataceae. Ed. E. KlienebergerNobel. London: Academic Press, Inc.

Razin, S. (1963). Osmotic lysis of Mycoplasma. J. gen. Microbiol. 33, 471.

Razin, S., Argaman, M. \& Avigan, J. (1963). Chemical composition of Mycoplasma cells and membranes. J. gen. Microbiol. 33, 477.

Razin, S. \& Oliver, O. (1961). Morphogenesis of Mycoplasma and bacterial L-form colonies. J. gen. Microbiol. 24, 225.

Razin, S. \& Rottem, S. (1963). Fatty acid requirements of Mycoplasma laidlaroii. J. gen. Microbiol. 33, 459.

Rodwell, A. W. (1956). The role of serum in the nutrition of Asterococcus mycoides. Aust. J. biol. Sci. 9, 105.

Rodwell, A. W. \& Aввотт, A. (1961). The function of glycerol, cholesterol and long-chain fatty acids in the nutrition of Mycoplasma mycoides. J. gen. Microbiol. 25, 201.

Rothblat, G. H. \& Sмiтh, P. F. (1961). Nonsaponifiable lipids of representative pleuropneumonia-like organisms. J. Bact. 82, 479.

Sierra, G. (1957). Studies on bacterial esterases. Part I. Differentiation of a lipase and two aliesterases during the growth of Pseudomonas aeruginosa and some observations on growth and esterase inhibition. Antonie van Leeurwenhoek J. Microbiol. Serol. 23, 241.

Sмiтн, P. F. (1959). Cholesterol esterase activity of pleuropneumonia-like organisms. $J$, Bact. 77, 682.

SmITH, P. F. (1963). The role of sterol in the growth and physiology of pleuropneumonialike organisms. Recent Progress in Microbiology, vir, p. 518. Ed. by N. E. Gibbons. Toronto: University Press.

Smith, P. F. \& Boughton, J. E. (1960). Role of protein and phospholipid in the growth of pleuropneumonia-like organisms. J. Bact. 80, 851.

Tourtellotte, M. E., Jensen, R. G., GaNder, G. W. \& Morowitz, H. J. (1963). Lipid composition and synthesis in the pleuropneumonia-like organism Mycoplasma gallisepticum. J. Bact. 86, 370.

Wycoff, H. D. \& Parsons, J. (1957). Chromatographic microassay for cholesterol and cholesterol esters. Science, 125, 347. 


\section{EXPLANATION OF PLATE}

Fig. 1. Detection of lipolytic activity in fractions collected during anion-exchange chromatography of Mycoplasma gallisepticum proteins. Plates contained $0 \cdot 4 \%(w / v)$ tributyrin dispersed in $0.02 \mathrm{M}$-phosphate buffer $(\mathrm{pH} 7.5)$ and $0.9 \%(\mathrm{w} / \mathrm{v})$ Bacto-agar (purified). Drops (0.02 ml.) of the chromatographic fractions were placed on the plate, and lipolytic activity determined after incubation at $37^{\circ}$ for $24 \mathrm{hr}$.

Fig. 2. Hydrolysis of tributyrin by various Mycoplasma strains. Drops (0.02 ml.) of washed suspensions of organism were placed on Edward medium plates containing $0.4 \%(\mathrm{w} / \mathrm{v})$ tributyrin; incubation at $37^{\circ}$ for $48 \mathrm{hr}$. $1=$ Mycoplasma laidlawii strain $\mathrm{A} ; 2=\mathrm{M}$. laidlawii strain $\mathrm{B}$; $3=$ M. mycoides var. capri; $4=M$. gallisepticum $(R) ; 5=$ boiled organisms of $M$. gallisepticum $(\mathrm{R}) ; 6=0.02 \mathrm{ml}$. crude pancreatic lipase solution (1 mg. $/ \mathrm{ml}$.). 

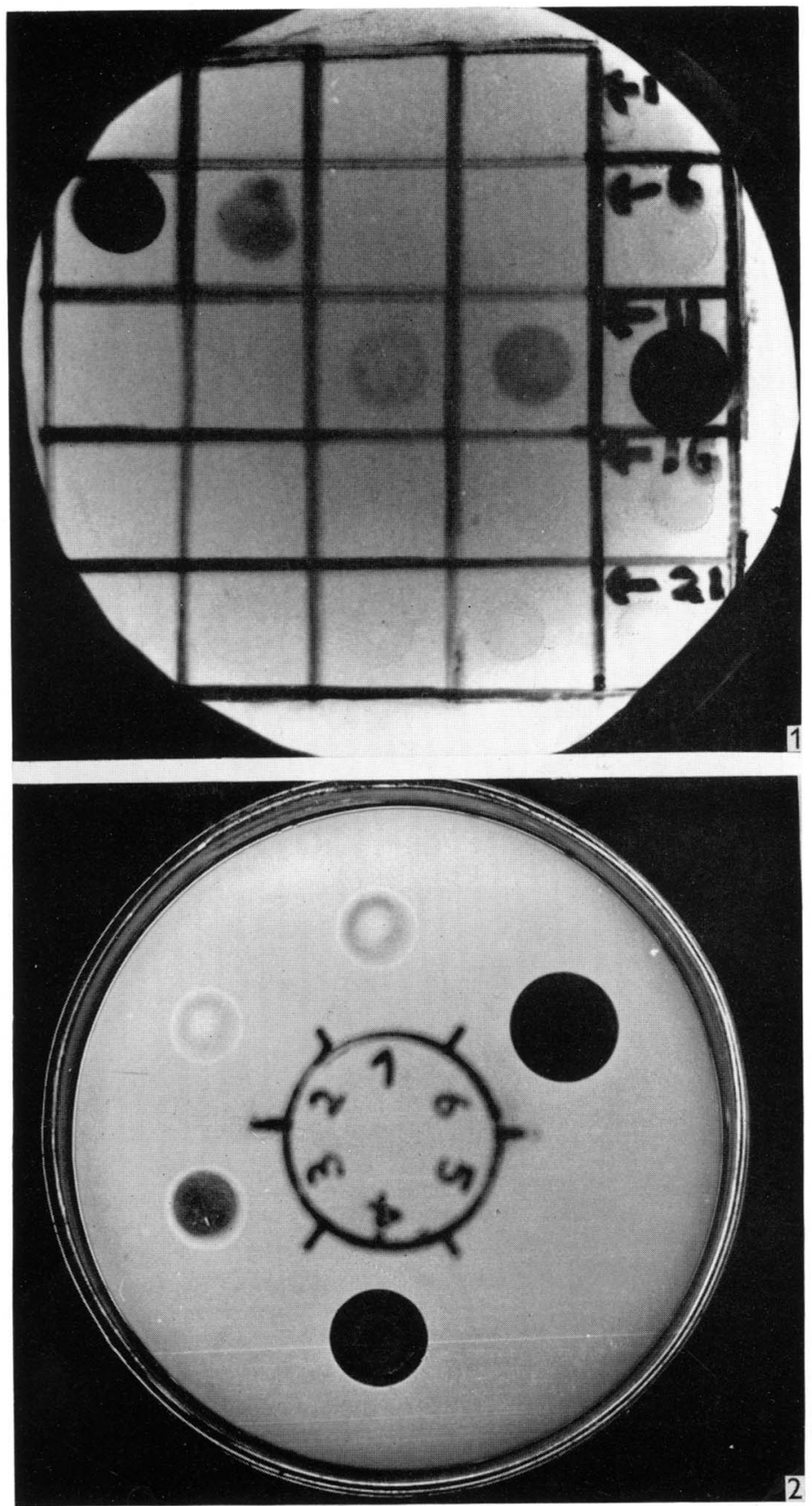